\title{
Resilience and coping in difficult social situations among children from low socioeconomic families
}

\author{
Beata Pastwa-Wojciechowska (1D ${ }^{A, D, E, F, G}$, Joanna Koralewska-Samko (D) A,B,C,D,E,F, \\ Mateusz Lammek $\mathbb{D D}^{\mathrm{C}}$ \\ Institute of Psychology, University of Gdansk, Gdansk, Poland
}

\section{BACKGROUND}

The study aimed to compare factors influencing social adaptation of children from families at risk of social exclusion versus their peers with higher socioeconomic status. The analysis applied to coping strategies in difficult social situations as well as intrapersonal and interpersonal attitudes, and attitudes towards the world.

PARTICIPANTS AND PROCEDURE

The study involved 169 children (girls $n=85$, boys $n=84$ ) aged 13-14 years. Children were included in the criterion group based on a statutory minimum subsistence level applicable for a given year in Poland.

\section{RESULTS}

Children with higher levels of resilience scored high in cognitive-intellectual and physical spheres as well as in personality, pro-social, socio-moral and support spheres and the sense of efficacy. Factors such as socioeconomic status and family structure were found to differentiate children in terms of coping mechanisms and attitudes towards themselves, other people and the world.

\section{CONCLUSIONS}

The study revealed that the child's psychological resilience is of particular importance for social adaptation.

KEY WORDS

mental resources; coping in difficult situations; poverty

CORResPonding AUthor - Prof. Beata Pastwa-Wojciechowska, Institute of Psychology, University of Gdansk,

4 Bażyńskiego Str., 80-309 Gdansk, Poland, e-mail: beata.pastwa-wojciechowska@ug.edu.pl

AUthors' CONTRIBUtion - A: Study design - B: Data collection - C: Statistical analysis - D: Data interpretation .

E: Manuscript preparation · F: Literature search · G: Funds collection

to Cite this ARticle - Pastwa-Wojciechowska, B., Koralewska-Samko, J., \& Lammek, M. (2021). Resilience and coping

in difficult social situations among children from low socioeconomic families. Current Issues in Personality

Psychology, 9(4), 299-305.

RECEIVED 05.05.2021 · REVIEWED 17.06.2021 · ACCEPTED 17.06.2021 · PUBLISHED 29.10.2021 


\section{BACKGROUND}

It was assumed that factors such as extreme poverty or permanent absence of one of the care providers negatively affect children's coping in difficult social situations as well as their intrapersonal and interpersonal attitudes and attitudes towards the world. The more dysfunctional factors affect them, the worse their functioning is, as manifested by their behaviour. As a result, children develop forms of improper behaviour and use less effective coping strategies. Numerous empirical studies and theoretical considerations support the adopted assumptions (Gawlina, 2006; Łukaszewska, 2010; Sygit-Kowalkowska et al., 2017; Yildiz, 2017). In line with the hypothesis, the present study focused on determining the impact of dysfunctional factors on children's coping in difficult situations and their attitude towards themselves, other people and the world, as well as on the role of psychological resilience as a resource protecting the child against the development of behavioural disorders. In line with current knowledge, the risk of developmental disorders in the mental and social spheres increases with the coexistence of dysfunctional factors, which may result in difficulties in the child's social functioning (Masten \& Powell, 2003; Radochoński, 2009). The literature on the subject presents concepts and theories referring to single or multiple human factors or traits that explain the unsatisfactory functioning. The cognitive approach assumes that the cognitive assessment of the situation is of great importance (Ostaszewski, 2008). On the other hand, the regulative theory of temperament emphasizes the importance of the relationship between temperament and the choice of stress coping strategy (Strelau, 1993). Human resources include temperamental and personality traits as well as material goods and relational skills. People differ in the ways they react to difficult situations, depending on the resources they have. We can speak of universal resilience when an individual copes well in all problematic situations, or partial resilience when an individual copes according to their practised skills. People with greater resilience to stressors show less negative emotions and lower emotional arousal, which favours efficacy.

One of the first studies, conducted by Rutter (1987), contributed to the creation of a list of family factors that affect the child's development: risk factors (marital conflicts, low social status, numerousness, mother's mental disorders, contact of the child with care institutions, and parental delinquency) and protective factors (parental support, correct parenting style, positive temperamental traits, female gender). This observation inspired researchers studying children brought up in adverse family conditions to search for factors protecting against psychopathology (Opora, 2011). Good adaptation of these children to the environment began to be explained with the concept of psychological resilience (Masten, 2001). According to Fredrickson, such a permanent resource of an individual emerges in a difficult situation (Ogińska-Bulik \& Juczyński, 2008).

Children from maladaptive families are referred to as children from the risk group. For example, the probability of emotional problems and aggressive behaviour in children brought up in reconstructed families is twice as high as in children from full families (Borucka \& Pisarska, 2010). Longitudinal child development studies show that from $30 \%$ to $70 \%$ of children growing up in adverse conditions and experiencing numerous traumas are characterized by considerable psychological resilience (Grzegorzewska \& Cierpiałkowska, 2012). It was concluded that both the existing crises and the risk of their likelihood may promote personal development and health (Sęk, 2004). In his research, Klohnen (1996) demonstrated that children with higher resilience are characterized by a higher sense of meaningfulness, self-confidence, self-esteem and a more positive attitude towards the world. They also find it easier to establish cordial relations and cooperate with others. They are diligent and helpful, which makes it easier for them to receive support and satisfy their own needs. Thus, a positive relationship was found between psychological resilience and problem-solving strategies. In turn, a negative relationship was established for coping with difficult emotions. Resilient children handle pressure and stress without sudden reactions and quickly return to balance by regenerating their resources (Opora, 2011).

\section{AIM}

The study aimed to assess the importance of psychological resilience when coping with difficult social situations as well as intrapersonal and interpersonal attitudes and attitudes towards the world of children from low socioeconomic families. The study analysed strategies for coping in difficult social situations as well as intrapersonal and interpersonal attitudes and attitudes towards the world that depend on the mental resources of children. The study was oriented towards answering the following research question:

1. Does resilience differentiate the way children brought up in low-income families cope in difficult social situations, depending on their level of psychological resilience?

2. Does resilience differentiate children's attitudes towards themselves, other people and the world depending on family factors?

3. Do the interactions between the studied variables (poverty, lack of one of the care providers, psychological resilience) differentiate children in terms of coping in difficult social situations, as well as their intrapersonal and interpersonal attitudes and attitudes towards the world? 
The children participating in the study were assigned to groups considering their individual trait resilience (high, low) according to their test results.

\section{PARTICIPANTS AND PROCEDURE}

\section{PARTICIPANTS}

The study involved 169 children (girls $n=85$, boys $n=84$ ) aged 13-14 years. Taking into account the family income, two groups of the children were formed - the first group consisted of children from "low-income families" $(n=84)$, where the income per family member did not exceed 754 PLN (from 1st November 2017). The second group included children from above-average income families, where the income per family member was around the national average of 1,300-1,600 PLN net $(n=85)$. Moreover, in both groups the following criteria were taken into account: the number of siblings, grade average, receiving assistance from the Municipal Family Support Centre, parents' education, and parents' professional work.

\section{MEASURES}

The following methods were used in the study: Questionnaire of Coping Strategies in Difficult Social Situations (Kwestionariusz radzenia sobie w trudnych sytuacjach społecznych, RTSS) by Borecka-Biernat (2003). It measures the way children cope with difficult situations by choosing one of three strategies: aggressive (A), evasive (U) or rational, task-oriented (R). The reliability of the tool was measured using competent judges. All correlation coefficients for test and test reliability are statistically significant at $p<.05$.

Questionnaire of Intrapersonal and Interpersonal Attitudes and Attitudes Towards the World (Kwestionariusz nastawień intrapersonalnych, interpersonalnych i nastawień wobec świata, KNIŚ) by Aksman and Wysocka (2011). Intrapersonal attitudes are understood as self-image and global self-esteem consisting of general and specific self-esteem, shown in various spheres of functioning: cognitive-intellectual, physical, socio-moral, and characterological. Interpersonal attitudes are defined as the image of other people and reciprocal relationships with people broken down into: "others vs. myself" (support, threat) and "myself vs. others" (pro-society approach, aggressiveness). Attitudes towards the world are understood as the world image, and beliefs about it. The internal compatibility of Cronbach's $\alpha$ is .90 for the entire scale, while for individual component scales the reliability ranges from .77 to .67 . The reliability of the test measured by Cronbach's $\alpha$ is .82 for the whole scale, while the internal compatibility established for the five subscales is between .76 and .87 .
Child Resilience Scale (Skala pomiaru prężności u dzieci, SPP-18) by Ogińska-Bulik and Juczyński (2011). The tool measures resilience, defined as a personality trait positively associated with the process of coping with traumatic events and stress in everyday life, as well as the adaptation process.

\section{PROCEDURE}

The research was preceded by obtaining permits for contact with children and their families from the directors of primary schools in the Pomeranian Voivodeship. The directors of the establishments were informed about the nature of the studies, their planned course, the objectives of the study and the location and form of the presentation of the results obtained. Parents of children participating in the study were also informed of the anonymity and voluntary participation in the study, as well as of the form and nature of the study and how and where the results were presented. During the discussions, written permission was collected from parents to examine the child. The consents obtained are in the possession of the authors of the study.

The study began with a parent interview, during which data were collected on the structure and functioning of the family and the support forms the family uses, such as family allowance. The data obtained from parents were confirmed with the Municipal Family Support Centre. The tests given to the children had the form of a paper-and-pencil questionnaire.

The data collected using the described study methods and procedures were subjected to statistical analysis using IBM SPSS Statistics 24 . First, the basic descriptive statistics were analysed, followed by a three-factor analysis of variance in the following system: financial situation $\times$ family structure $\times$ resilience with Sidak's post hoc test. The statistical significance level was deemed to be $p<.05$.

\section{RESULTS}

The study showed several differences between children with high and low resilience.

The main effect of resilience was found to be statistically significant in the cognitive-intellectual sphere: $F(1,169)=21.86 ; p<.001 ; \eta^{2}=.120$, characterological sphere: $F(1,169)=5.31 ; p<.05 ; \eta^{2}=.032$, pro-social sphere: $F(1,169)=4.58 ; p<.05 ; \eta^{2}=.028$ and socio-moral sphere: $F(1,169)=22.06 ; p<.001$; $\eta^{2}=.121$. High-resilient children scored higher in all of the above-mentioned dimensions. Additionally, the main effect of resilience was found to be statistically significant in terms of the received support: $F(1,169)=8.59 ; p<.01 ; \eta^{2}=.051$ and self-efficacy $F(1,169)=15.14 ; p<.001 ; \eta^{2}=.086$. Children with 
high levels of resilience scored higher on the scale of received support and assessed their self-efficacy higher. A main effect of resilience was also obtained for the lack of helplessness sphere: $F(1,169)=6.32$; $p<.05 ; \eta^{2}=.038$. Children with higher levels of resilience were characterized by higher scores on the lack of helplessness scale. This score shows that high-resilient children have a lower sense of helplessness.

Moreover, the main effect of resilience in the physical sphere was statistically significant: $F(1,169)=27.68 ; p<.001 ; \eta^{2}=.147$. In this dimension, the effect of the interaction of the financial situation and resilience also was found to be significant: $F(1,169)=2.82 ; p<.05 ; \eta^{2}=.018$. Children with high levels of resilience differ from children with low levels of resilience both when the families are lowincome $(p<.01)$ and when they are moderately welloff $(p<.001)$. In both cases, high-resilient children scored higher on the physicality scale (see Figure 1).

Taking into account the remaining variables, the main effect of financial status in the cognitive-intellectual sphere was found to be statistically significant: $F(1,169)=14.02 ; p<.001 ; \eta^{2}=.080$. Children from extremely low-income families obtained lower results on the scale than children from middle-income homes.

Also in terms of support, the main effect of the family structure was found to be statistically significant: $F(1,169)=5.12 ; p<.05 ; \eta^{2}=.031$. Children from one-parent families scored lower in the support sphere than children raised in full families. On the scale of the sense of efficacy, the main effect of the family's financial status was found to be significant: $F(1,169)=8.83 ; p<.01 ; \eta^{2}=.052$. Here, children living below the poverty line scored lower than children from middle-income homes.

\section{Figure 1}

The interaction of the family's economic situation and resilience in the physical sphere

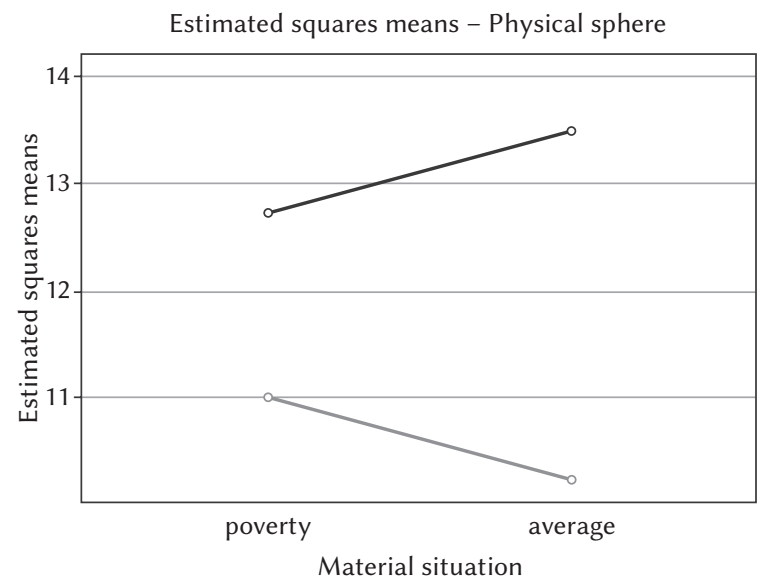

Resilience group

_ low level of resilience _ high level of resilience
For the lack of threat dimension, the main effect of the family structure was found to be statistically significant: $F(1,169)=9.23 ; p<.01 ; \eta^{2}=.054$. Children brought up in single-parent families score lower on the lack of threat scale than children from full families. This means that children from one-parent families report a higher level of a perceived threat than children from complete families. The interactions between the factors of family financial status and the family structure were also noted to be statistically significant: $F(1,169)=4.19 ; p<.05 ; \eta^{2}=.025$. The pairwise comparisons showed that children brought up in full families differ from children raised in broken families in terms of perceived threat for the group of children from middle-income families $(p<.01)$. Children brought up in middle-income, but incomplete, families, scored lower on the lack of threat scale than children from families where parents remain in a relationship. There were no differences in this respect in the group of low-income children. The analyses also showed a significant effect of the triple interaction of the material situation, family structure and resilience: $F(1,169)=3.45 ; p<.05 ; \eta^{2}=.021$.

\section{CHILDREN WITH HIGH LEVELS OF RESILIENCE}

The interaction of the economic situation and family structure was statistically significant: $F(1,121)=6.78$; $p<.05 ; \eta^{2}=.055$. Children from full families differ from children from one-parent families when the family is of average status $(p<.001)$. High-resilient children from complete, middle-income families feel less at risk (higher results on the No Threat Scale) than children with a similar level of resilience from middle-income one-parent families (see Figure 2).

\section{Figure 2}

The interaction of family structure and financial status on the sense of lack of threat in high-resilient children

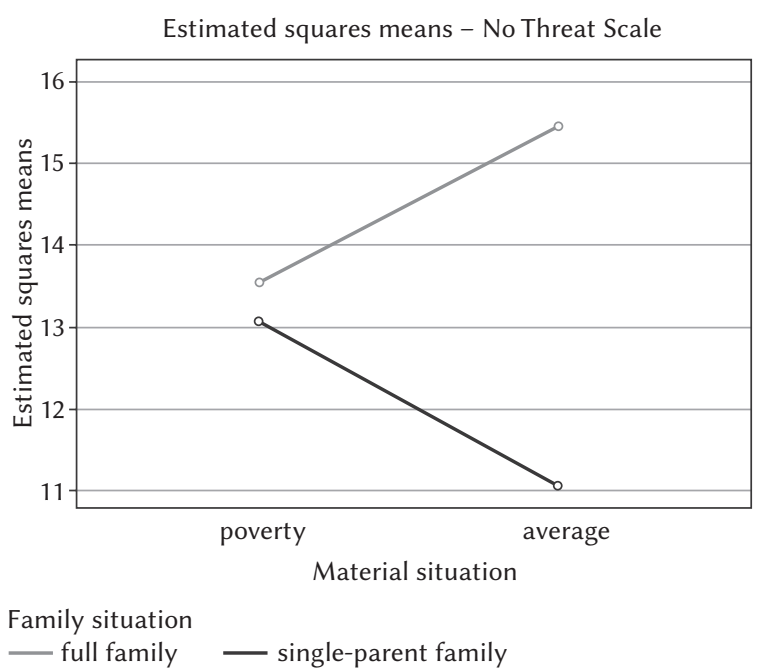


Additionally, studies have shown differences in the coping methods used by adolescents.

A main effect of resilience was obtained for the dimension of evasive coping in difficult social situations: $F(1,169)=7.45 ; p<.01 ; \eta^{2}=.044$. Children with low levels of resilience avoid coping more often than highresilient children. As for the aggressive style of coping with difficulties, the effect of financial status was found to be statistically significant: $F(1,169)=11.19$; $p<.01 ; \eta^{2}=.065$. In difficult social situations, children brought up in low-income families use aggressive style statistically significantly more often than children from middle-income families.

\section{DISCUSSION}

The development of cognitive and intellectual functions is affected by human activity and adequate stimulation from the environment, which may explain the lower scores of low-income children and low-resilience children on the cognitive-intellectual scale. In his culture of poverty theory, Lewis (1976) draws attention to the fact that children brought up in low-income families are often neglected in terms of care and satisfaction of needs. People living in poverty enclaves are constantly accompanied by "empty" time, which is not devoted to cognitive and intellectual stimulation. The analysis of this group shows that parents of extremely low-income children had, to a large extent, primary or vocational education, which may also translate into their children's scores. Parenting behaviours shape the specific behaviour of the children. Persons from poverty enclaves are characterized by a sense of inferiority, helplessness, and passiveness (Lewis, 1976). There is a link between long-term social assistance in the form of benefits and a lower sense of agency and efficiency. Taking advantage of social benefits becomes a lifestyle. The longer an individual collects the benefits, the more helpless, less independent and effective they become. People with low income lose the ability to be independent and they become convinced of being doomed to fail (Tarkowska, 2002). Children brought up by parents caught up in the "social welfare trap" inherit passive attitudes and lack of faith in their remedial abilities. Children from low-income homes may experience an imbalance between the effort they put in and the results they achieve. This may contribute to lower self-efficacy, which may be explained by the scores obtained in the study.

High-resilient children have a positive attitude towards the world and themselves, so they treat difficulties as a challenge to overcome and a chance for a new experience. Such an approach may favour the development of cognitive and intellectual functions. Children with high psychological resilience can ef- fectively cope with difficulties, so they function better and become successful, which increases their sense of self-efficacy. They are characterized by a higher sense of meaningfulness, self-confidence, self-esteem, and a sense of agency (Ogińska-Bulik \& Juczyński, 2011). High-resilient children are more focused on solving difficulties and less on coping strategies, which increases the likelihood of coping positively with the problem. Children who perceive the inability to decide their fate and cope with difficulties lose their motivation to take preventive actions. Persons with low psychological resistance react with more negative emotions and higher emotional arousal, which makes their action less effective. As result, they more often resort to evasive coping strategies.

Highly resilient children's positive attitude towards themselves and the world may explain their higher scores on the physical and characterological scales. These scales refer to the characteristics of selfesteem and the child's view of their external appearance and physical fitness as well as human functioning in terms of others and their disposition. Children characterized by high levels of resilience are better adapted to peer groups. They cope with interpersonal contacts much better and adapt to the rules of social life, which is confirmed by their higher score on the socio-moral scale. These children are more sympathetic to others. They are agreeable and less willing to hurt others as compared to children with low levels of resilience. Moreover, this trait can protect them from social maladjustment. Studies have shown that children with higher levels of resilience are more involved in pro-social behaviour than children with low levels of resilience. It is worth noting that this dimension is a part of a wider scale measuring the attitudes of "myself vs. others" within interpersonal functioning, while one of the dimensions of resilience is proper psychosocial functioning. Moreover, the literature on the subject shows the relationship between resilience and interpersonal skills, such as a sense of humour, ability to cooperate, proper peer relations, agreeableness, optimism in life, and reluctance to harm others (Ogińska-Bulik \& Juczyński, 2011).

The study demonstrated that children with higher resilience evaluate the received support higher than children with low resilience. This may result from the ability to establish social relationships that provide support. Resilient children have supportive parents much more often than children with low levels of resilience. The child's family structure is also important, as psychologists describe the breakdown of the family as a situation that threatens such values as love and a sense of security. The absence of one of the parents automatically reduces the family's resources, including the child's (less emotional and informational support, less financial resources, fewer role models). Our own research has shown that children from broken homes feel a higher level of threat. Moreover, if 
we take into account children brought up in average financial conditions, those who experienced their parents' divorce feel a higher level of threat. The situation is similar for children characterized by high levels of resilience. Comparing high-resilient children from middle-income homes, those brought up in broken families feel a higher level of threat. This shows the dysfunctional power of family breakdown on the child's sense of security, even when protective factors (high psychological resilience, higher sociomaterial status) are present. It should be remembered that the child's distorted sense of security may result from conflicts between the spouses, which often precede the actual separation.

\section{CONCLUSIONS}

Summarizing the conducted analyses, it can be concluded that:

1. Both risk factors and a child's mental resources are of particular importance for the social functioning of an individual. Children from low-income families differ from children from families with an average socioeconomic status in terms of such variables as a cognitive-intellectual, characterological, pro-social, socio-moral sphere, received support, sense of efficacy and helplessness.

2. As part of the preventive and socio-therapeutic programmes, it is necessary to focus more on children's resources by expanding school programmes with specially prepared action plans aimed at teaching children how to cope effectively using their resources.

3. It is necessary to address the forms and quality of social aid programmes as well as their availability. For such forms of assistance, it would be important to make people with a low income independent of social institutions, give them a chance to get out of the poverty enclave and re-adapt to the social environment.

4. Such aid programmes need to include elements of support addressed directly to children, thus levelling their start in the process of education and socialization, therefore counteracting the deepening sense of social exclusion.

\section{References}

Aksman, J., \& Wysocka, E. (2011). Kwestionariusz nastawień intrapersonalnych, interpersonalnych i nastawień wobec świata. Podręcznik testu - wersja dla uczniów szkoty podstawowej klas IV-VI [Questionnaire of intrapersonal and interpersonal attitudes and attitudes towards the world. Test manual version for primary school students, grades IV-VI]. Ministerstwo Edukacji Narodowej.
Borucka, A., \& Pisarska, A. (2010). Koncepcja resilience - czyli jak pomóc dzieciom i mtodzieży z grup podwyższonego ryzyka [The concept of resilience - or how to help children and adolescents from highrisk groups]. Pracownia Profilaktyki Młodzieżowej Pro-M.

Borecka-Biernat, D. (2003). Kwestionariusz radzenia sobie w trudnych sytuacjach społecznych [Questionnaire of coping strategies in difficult social situations]. Przeglad Psychologiczny, 46, 9-36.

Gawlina, Z. (2006). Małżeństwo i rozwód w opinii młodzieży [Marriage and divorce in young people's opinion]. Roczniki Socjologii Rodziny, 17, 83-99.

Grzegorzewska, I., \& Cierpiałkowska, L. (2012). Realizacja zadań rozwojowych przez młodzież z rodzin z leczącym się i pijącym ojcem alkoholikiem [Developmental tasks accomplishment by youth from families with treated and drinking alcohol father]. Polskie Forum Psychologiczne, 17, 5-26.

Klohnen, E. C. (1996). Conceptual analysis and measurement of the construct of ego-resiliency. Journal of Personality and Social Psychology, 70, 1067-1079. https://doi.org/10.1037/0022-3514.70.5.1067

Lewis O. (1976). Nagie życie [Naked life]. Państwowy Instytut Wydawniczy.

Łukaszewska, J. (2010). Ubóstwo i zamożność - różnice stylów życia [Poverty and affluence - differences in lifestyles]. In R. Szarfenberg, C. Żołędowski, \& M. Theiss (Eds.), Ubóstwo i wykluczenie społeczne - perspektywa poznawcza [Poverty and social exclusion - a cognitive perspective] (pp. 86-97). Elipsa.

Masten A. (2001). Ordinary magic. Resilience processes in development. The American Psychologist, 56, 227-238. https://doi.org/10.1037//0003-066x.56. 3.227

Masten, A., \& Powell, J. (2003). A resilience framework for research policy and practice. In S. Luthar (Ed.), Resilience and vulnerability (pp. 1-28). Cambridge University Press.

Ogińska-Bulik, N., \& Juczyński, Z. (2008). Skala pomiaru prężności - SPP-25 [Resilience Scale - SPP-25]. Nowiny Psychologiczne, 3, 39-56.

Ogińska-Bulik, N., \& Juczyński, Z. (2011). Prężność u dzieci i młodzieży: charakterystyka i pomiar polska skala SPP-18 [Resilience in children and adolescents: characteristics and measurement Polish scale SPP-18]. Polskie Forum Psychologiczne, 16, 7-28.

Opora, R. (2011). Nieletni niedostosowani społecznie, lecz odporni psychicznie [Juveniles socially maladjusted but mentally resistant]. In W. Junik (Ed.), Resilience. Teoria - badania - praktyka [Resilience. Theory - research - practice] (pp. 29-44). Parpamedia.

Ostaszewski, K. (2008). Czynniki ryzyka i czynniki chroniące w zachowaniach ryzykownych dzieci i młodzieży [Risk factors and protective factors in risky behaviors of children and adolescents]. 
In J. Mazur, J. Tabak, A. Małkowska-Szkutnik, K. Ostaszewski, H. Kołoło, A. Dzielska, \& A. Kowalewska (Eds.), Czynniki chroniące mtodzież 15-letnia przed podejmowaniem zachowań ryzykownych [Factors protecting 15-year-old adolescents from engaging in risky behaviors] (pp. 19-44). Instytut Matki i Dziecka, Zakład Ochrony i Promocji Zdrowia Dzieci i Młodzieży.

Radochoński, M. (2009). Psychopatologia życia emocjonalnego dzieci i młodzieży. Wybrane zagadnienia [Psychopathology of emotional life of children and adolescents. Selected issues]. Wydawnictwo Uniwersytetu Rzeszowskiego.

Rutter M. (1987). Psychosocial resilience and protective mechanisms. The American Journal of Orthopsychiatry, 57, 316-331. https://doi.org/10.1111/j. 1939-0025.1987.tb03541.x

Sęk, H. (2004). Psychologia ryzyka, zdrowie i zachowania zdrowotne w kontekście rozwoju psychoseksualnego człowieka i jego zaburzeń [Risk psychology, health and health behaviors in the context of human psychosexual development and its disorders]. In M. Beisert (Ed.), Seksualność w cyklu życia człowieka [Sexuality in the human life cycle] (pp. 6184). Zakład Wydawniczy K. Domke.

Strelau, J. (1993). The location of the regulative theory of temperament (RTT) among other temperament theories. In J. Hettema \& I. J. Deary (Eds.), Foundations of personality (pp. 113-132). Springer.

Sygit-Kowalkowska, E., Szrajda, J., Weber-Rajer, M., Porażyński, K., \& Ziółkowski, M. (2017). Prężność jako predyktor zdrowia psychicznego kobiet odbywających karę pozbawienia wolności [Resilience as a predicator of mental health of incarcerated women]. Psychiatria Polska, 51, 549-560. https://doi.org/10.12740/PP/OnlineFirst/62617

Tarkowska, E. (2002). Zróżnicowanie polskiej biedy w świetle badań jakościowych [Differentiation of poverty in Poland: qualitative research studies perspective]. Problemy Polityki Spotecznej, 4, 119-132

Yildiz, M.A. (2017). Pathways to positivity from perceived stress in adolescents: Multiple mediation of emotion regulation and coping strategies. Current Issues in Personality Psychology, 5, 272-284. https://doi.org/10.5114/cipp.2017.67894 